\title{
A flexible and concerned European Union - A new proposal
}

\section{BRUNO DALLAGO ${ }^{1 *}$ (D) and STEVEN ROSEFIELDE ${ }^{2}$ (B)}

\footnotetext{
${ }^{1}$ Department of Economics and Management, University of Trento, Via Inama 1, 38122 Trento, Italy

${ }^{2}$ Department of Economics, University of North Carolina at Chapel Hill, Chapel Hill, NC, USA
}

Received: January 19, 2020 • Revised manuscript received: April 16, 2020 • Accepted: June 15, 2020

(C) 2021 Akadémiai Kiadó, Budapest

\begin{abstract}
The paper proposes the construction of a multi-speed, multi-track and multi-level European Union framework as a way to increase the flexibility of the integration process and facilitate inter-country conflict resolution. The paper shows that this malleable framework is superior, even for sensitive macroeconomic spillover issues like monetary union and immigration.
\end{abstract}

\section{KEYWORDS}

crisis, Eurozone, European Union, institutions, policies, reforms

\section{JEL CLASSIFICATION INDICES}

E02, E61, F15, G01, 052

\section{INTRODUCTION}

The Treaty of Rome, which created the European Economic Community (EEC) in 1958 among the six founding countries and established the European Commission (EC), was the first comprehensive move in the process of European integration. ${ }^{1}$ The Treaty foresaw the

\footnotetext{
*Corresponding author. E-mail: bruno.dallago@unitn.it
}

\footnotetext{
${ }^{1}$ The establishment of the European Coal and Steel Community through the 1951 Treaty of Paris was the precursor involving the same countries. It established the principle of supranationality and was meant as a first step towards a European Federation. Yet it was a partial undertaking limited to two, albeit fundamental industries.
} 
creation of a single market for goods, labour, services and capital through the reduction of customs duties and the establishment of a customs union. It also provided for the creation of common policies for agriculture and transport and established a European Social Fund for supporting employment and promoting economic and social cohesion. Although the Treaty aimed mainly to create a common market and coordinate the action of sovereign member countries, it also served as a waystation on the road to a fully integrated European Union (EU).

The Treaty reflected the view that a progressive one-track approach would resolve the potential conflicts in fiscal and trade issues through pragmatic, long-term bargaining and empathetic compromise. Although in the Treaty this was limited mostly to markets and trade, a series of interpretative judgments by the European Court of Justice established the EEC's legal supremacy in selected fields. The prevailing view became that member countries should adopt a single-track framework (uniform goals, guidance, rules and regulations) in issues of EU competence and travel together at the same speed by consecutively negotiating treaties in lieu of an EU constitution (Scicluna 2018). Following the subsequent waves of enlargement, this one-speed, one-track, one-level (OSTL) principle was relaxed for the less developed new member countries (including former socialist countries), granting them a breathing room to successfully adapt to the common framework and modernize. This accommodation preserved national pluralism as an important aspect of the integration process. ${ }^{2}$ However, it proved inadequate for amicably resolving ensuing shocks and conflicts. We suggest that the best approach to dealing with the current EU challenge is to abandon the one-size-fits-all integration framework and switch to a multi-speed, multi-track and multi-level (MSTL) European Union strategy.

The paper is organized in six sections. Section 1 attributes the need for MSTL primarily to the challenges posed by the 1992 Maastricht Treaty. Section 2 analyses these challenges and sketches various solutions proposed in the recent literature. Section 3 explains why and in what sense a MSTL solution may be superior. Section 4 delves into the advantages of an MSTL solution for resolving contentious migration and monetary union disputes. Section 5 surveys competing proposals. Section 6 showcases the advantages of MSTL, and Section 7 concludes.

\footnotetext{
${ }^{2}$ The division of competences within the EU is regulated in the Treaty of Lisbon on the basis of the principle of conferral, according to which the EU may only act within the limits of the competences conferred upon it by the member countries. Competences not conferred upon the EU in the Treaties remain with the member countries. The Treaty divides competences into 3 main categories: a. exclusive competences, mostly of economic character (e.g., customs union, monetary policy for the Eurozone countries); b. shared competences between the EU and the member countries (e.g., internal market, selected social policy aspects, cohesion policy and research); and c. supporting competences to support, coordinate or complement the action of the member countries (e.g., health, culture and education). The EU can also take measures to ensure that the member countries coordinate their economic, social and employment policies and have competences in pursuing a common foreign and security policy. The allocation of competences is submitted to the principles of proportionality (by mean of which the content and scope of the EU action may not go beyond what is necessary to achieve the objectives of the Treaties) and subsidiarity (the EU takes action only when it is more effective than action taken at the national, regional or local level).
} 


\section{SETTING THE STAGE}

The EU's leadership's desire for "more Europe" took a fundamental step forward when the Maastricht Treaty put monetary integration on the agenda in 1992, requiring all member countries to join the monetary union as soon as they were ready, with the exceptions of Great Britain and in part Denmark. In absence of political union, monetary integration imposes stringent rules and requires more member country coordination than a common trade regime. In the years preceding the global financial crisis of 2008 "more Europe" supporters dominated, but the spirit of unity frayed after the crisis. EU leaders still expect the union to weather the financial crisis on a pragmatic learning-by-doing basis and find it difficult to contemplate the union's fragility. Their optimism may be misplaced because the EU institutions are coping poorly with internal and external frictions roiling public policy. These conflicts are being addressed with inefficient substitutes for an institutional solution.

Returning to the basics offers a more promising approach. The essential point is that the Common Market (now the Single Market) no longer provides a strong enough bond to sustain EU solidarity because the EU is triple-minded. Members invoke the win-win logic of Pareto competition in embracing the single market but follow a different logic in two other important matters. First, they prefer socially managed markets to laissez-faire hoping to reconcile efficiency with equity. This gives rise to inter-member disputes over regulatory power. Pareto bargaining is always a win-win when market failures are absent, whereas the socially managed markets are not. Socially managed markets may create winners and losers of various sorts depending on who holds the reins of power. Regulators try to allay fears with promises of roundabout synergies, but as Greece discovered, assurances that austerity's benefits will outweigh its costs may be invalid. Second, the strong EU members may pressure others, claiming to act for the collective good.

Regulatory conflicts and brow beating occur in all political systems. They come with the territory and in good times are manageable with a commitment to solidarity, common sense and supportive institutions. These conditions were satisfied before the Maastricht Treaty, lubricated by the shared fruits of trade liberalization and healthy competition. Solidarity, however, in recent years seems to be weakening. Future gains from the single market appear modest, pressure for "more Europe" continues to generate stiff resistance, and a clash of rival social and political demands is testing EU pragmatism.

The literature has taken notice. Andreozzi - Tamborini (2019) show that technocratic regimes are dominated by non-cooperation, suggesting that the EU leaders may be conditioned to favour hard choices between the union and non-cooperation. Bellamy - Kröger (2017) argue that non-cooperation can be softened if leaders can be persuaded to accept differentiated integration on democratic grounds of fairness, impartiality and equity. Wahl (2017) sees the possibility of coalitions of the willing selectively finding common ground on the integration issues. De Witte (2018) reviews the recent surge of interest within the EU in pursuing new projects of differentiated integration and discusses their legal and political feasibility. Telò (2017) and Ling (2017) probe the nuances. Fabbrini (2019) proposes the decoupling and reforming of the EU, separating the economic community of the single market, and a Eurozone political union.

Sensitizing policymakers to the importance of fairness, impartiality and equity, and experiments with new types of integration have merit. MSTL, however, is more general. It subsumes most of the suggestions made by others and is consistent with the EU founders' accommodative 
supranational spirit (Scipioni 2018). It will eliminate unnecessary compulsion; diminish polarization, foster local adaptation, and tailor speed and adaptation to circumstances, creating a space for all EU members to flourish in the ways they consider the best.

MSTL differs from established practices - such as the Open Method of Coordination and some countries' opt-out possibilities from the Monetary Union or Schengen Agreement or the Common Foreign and Security Policy. It tries to diminish the risk of ad hoc opt-outs by designing more flexible and transparent institutions.

\section{MSTL UNION}

EU's pressure for "more Europe" and promotion of OSTL obscure the diagnosis of the union's discontents. Intra-union conflicts are generated by the disorderly character of MSTL (Brunnermeier et al. 2016; Mody 2018). MSLT itself is not to blame. We contend that an orderly MSTL is sufficient to significantly mitigate strife and promote better outcomes.

Multi-speed integration means that the member countries go in the same direction and pursue common goals but do so at different speeds. Some countries are faster and reach the goal sooner. Others are slower and need more time. The integration process may also be multi-track, where some countries pursue more integration, others less. For instance, a group of countries may enter the monetary union sharing the same currency, monetary institutions and policies, while other countries are content with being partners in a common market. Although this arrangement is easy to implement because it respects national preferences, it risks creating a heterogeneous union without a common progressive identity (Pisani-Ferry 2014).

Multi-level integration adds a third element. The term refers to the endpoints of the integration process, which are open to discussion as the members proceed along different paths. In a MSTL union, the member countries pursue similar goals, but do this in different ways at different speeds, along different tracks and at different levels in accordance with their circumstances. Members may also seek objectives that other partners dislike, but are willing to tolerate. Unanimity is inessential in most cases. The rationale behind the multi-track solution is that the member countries are different: they have different resources and capabilities, different institutions and structures and need to solve different problems. If they want to achieve common goals, they may have to go at different speeds, along different tracks and at different levels in solving different problems in different ways and using different economic and financial approaches. The main challenge of MSTL integration, with acceptable diversity is the management of onerous macroeconomic spillovers and the danger of moral hazard that transform the win-win into win-lose situations. There is a pressing need for proper measurement, assessment and enforcement to cope effectively with the divisive spillovers and moral hazard.

MSTL's primary virtue is the freedom enjoyed by the member countries to determine the use their own resources, constrained by the shared responsibilities to minimize negative spillovers and moral hazard. More national freedom combined with joint responsibility based on transparent rules and procedures promise superior results, and political stability. It will make the EU stronger because cooperation will be upgraded, internal conflicts softened and decision-making concentrated on solving the most demanding problems, from energizing growth to intercountry cooperation in line with the Europe 2020 Strategy. 
The MSTL reinterprets the spirit of the European integration in the Saint-Simonian tradition as a cooperative club with membership levels (supranational, national and joint) designed to suit different tastes and while simultaneously protecting members with special needs (Saint-Simon 1814). The concept allows the members to maximize utility without jointly optimizing wellbeing, subject to the critical benevolent constraints according to a single Bergsonian social welfare standard (Bergson 1938, 1954, 1976). The Paretian and Bergsonian metrics are identical if the members have common preferences and values. If everyone agrees then whatever EU institutional order all select will be the best. If members do not agree, some will necessarily be displeased and may try to harm others deliberately or inadvertently by exerting de facto regulatory power and imposing paternalistic values. The EU leaders doubtlessly are aware that the Paretian and Bergsonian utility optimizations are never the same; that conflict is endemic in all systems, and that they therefore must choose between a one-class membership club and a MSTL confederation, but for decades, they have pretended that the benefits of a unitary order outweigh the costs.

The pretence is misguided. It not only has been detrimental for some members, it tarnished the transnationality's appeal. Switching to a MSTL confederation, especially one that deals with spillovers may relieve fears and facilitate cooperation, including acceptance of mutually amendable "more Europe" policies. Finally, the cooperative club proposal may help avoid the backlash from endless economic and social crises and the revival of forms of disruptive nationalism and localism, and guarantee respect for the fundamental EU principles (basic freedoms and subsidiarity).

The problem lies in the conflicts and spillovers among the participating countries that are exacerbated by a one-size-fits-all OSTL framework. It is better to have an explicit, inclusive and orderly MSTL union than to pursue a disorderly and inconsistent unitary federal integration (Acemoglu - Robinson 2012; Rosefielde - Pfouts 2014). The present EU MSTL is anything but an idea, caught as it is between the illusion of self-adjusting markets and the power of ordoliberal discipline. A rationalized and explicit MSTL EU would help the EU move toward a flexible inclusive integration.

\section{THE PRESENT EU ARCHITECTURE AND NATIONAL INSTITUTIONAL IDIOSYNCRASIES}

European integration sought:

a) peace and democracy in the war-torn Europe,

b) production and trade integration to deter armed conflicts,

c) reduced transaction costs and strengthened scale and scope economies to improve enterprise competitiveness,

d) increased size to make the integrated economy more resilient to crises and improve Europe's standing in the international markets.

The Monetary Union subsequently sought additional micro- and macroeconomic management efficiencies.

These aims were politically ambitious, yet technically feasible. All countries were in similar situations: dynamic growth thanks to the post-war reconstruction period, rapidly growing 
openness of economies in a globalizing international context and strong willingness to cooperate. The member countries were confident that this was the best way for the former colonial powers to regain a central place and role in the international arena.

The original shared vision was OSTL: all countries had to proceed in the same way at the same time towards the same goals, although concessions due to exceptional circumstances and within clear limits were foreseen. ${ }^{3}$ This trajectory became evident with the implementation of the Economic and Monetary Union (EMU), but became disorderly through series of opt-outs from common rules as soon as the Union enlarged. ${ }^{4}$

It yielded high initial dividends by focusing on the Pareto superior common market building, allowing everyone to gain without compelling any member to lose. Widened rational utilitarian choice outweighed conflicts over monetary and fiscal policy and social values. The financial crisis of 2008 shattered the euphoria. The game ceased being unambiguously Pareto superior, morphing into an asymmetric power and social order game (Stiglitz 2016).

In fact, the EU integration did become a multi-speed process in different senses. First, the convergence to the Maastricht parameters was never iron clad. Italy and Belgium acceded to the Eurozone in 1997 despite public debts exceeding 60\% of GDP. Most Eurozone countries had public deficits, and some had public debts exceeding the levels foreseen in the convergence parameters. The process of compliance with the convergence criteria is quite uneven among the Eurozone member countries. In spite of the need for all member countries to join the monetary union, seven member countries failed to do so, while some (Sweden and the Czech Republic) non-EMU members comply with the convergence criteria better than many Eurozone countries. Two countries (Great Britain through negotiations and Denmark following a referendum) obtained opt-outs from adopting the euro. In other areas, new members from Central and East Europe postponed agricultural land ownership liberalization for several years. Newly independent countries refused for years to grant citizenship to a significant part of their inhabitants. Some countries refused to accept and implement commonly agreed refugee quotas. The Schengen Agreement was partially suspended during the Covid-19 pandemic in 2020.

These examples demonstrate that the Eurozone itself is an inconsistent MSTL, not a wellfunctioning OSTL regime. Countries pursue the same goal (the same currency with the same monetary policy and macroeconomic and fiscal equilibrium in order not to jeopardize the stability of the currency) at different speeds, through different tracks (some countries have to stabilize and others not, some grow, and others stagnate, some decrease their debt and others increase it), at different levels.

\footnotetext{
${ }^{3}$ Article 93, $\S 2$ of the 1957 Treaty of Rome stipulated: “On application by a Member State, the Council, may, acting unanimously, decide that aid which that State is granting or intends to grant shall be considered to be compatible with the common market, in derogation from the provisions of Article 92 or from the regulations provided for in Article 94, if such a decision is justified by exceptional circumstances."

${ }^{4}$ Some member countries negotiated particular opt-outs from legislation or treaties of the EU that in principle apply to all member countries. There are currently five opt-out areas involving four countries: Ireland and the United Kingdom from implementing the Schengen agreement; the UK from the monetary union while Denmark has the right to decide if and when to join the euro; Poland and the UK have partial opt-out about how the Charter of Fundamental Rights of the EU interacts with the national law; Denmark, Ireland and the UK have opt-outs from the area of freedom, security and justice.
} 
The EU has chosen to distort its de facto institutions rather than revise the treaties. Ultimate economic sovereignty still reposes in national governments, with the exceptions of the monetary sovereignty, which operates with a strict monetary mandate (price stability) under an incomplete common organ (the ECB). While joint sovereignty encourages cooperation, it disregards the growing disparity among the member countries. Pressed by a prolonged economic and financial crisis and growing domestic social and political pressure, aggravated by the 2020 pandemic, various countries are increasingly resisting common rules and enforcement and demanding change. An explicitly well ordered MSTL EU based on transparent institutions and processes would be better.

\section{IMMIGRATION AND THE MONETARY UNION}

The management of immigration and the monetary union have proven to be especially challenging. Experience has revealed that the EU copes satisfactorily with immigration and euro management in tranquil times, but not under duress. The EU defines the conditions governing entry of immigrants in the member countries, without aiming at harmonizing national laws and regulations. It may provide incentives and support to countries and has to deter irregular immigration, particularly through return policies to the third countries of origin. The member countries determine the numbers of admitted immigrants. The present regime for asylum seekers is based on the Dublin System which includes the Dublin Regulation and the European Dactyloscopy (Eurodac), the EU fingerprint database used for identifying the refugees and irregular immigrants. The Dublin III Regulation presently in force (Regulation 604/2013) makes each EU member country responsible for examining asylum seeker applications within the EU, under the Geneva Convention and the EU Qualification Directive. It strives to assure prompt and equitable processing, while preventing immigrants from filing multiple applications in different countries because if the entrance country accepts them, they gain the right to reside anywhere in the Schengen area.

The management and inter-country distribution of refugees and immigrants is clear and sensible on paper ${ }^{5}$ but was overwhelmed by a massive influx of refugee applicants in the summer of 2015. The pressure at the external border and within the EU stressed national governments. Hungary for all intents and purposes withdrew from the Dublin Regulation, closing its borders to immigration and refusing to accept returnees who had entered Hungary first but crossed over to other EU countries. Germany and the Czech Republic appealed Hungary's unilateral action

\footnotetext{
${ }^{5}$ In the EU a refugee is "either a third-country national who, owing to a well-founded fear of persecution for reasons of race, religion, nationality, political opinion or membership of a particular social group, is outside the country of nationality and is unable or, owing to such fear, is unwilling to avail themselves of the protection of that country, or a stateless person, who, being outside of the country of former habitual residence for the same reasons as mentioned above, is unable or, owing to such fear, unwilling to return to it, and to whom Art. 12 (Exclusion) of Directive 2011/95/ EU (Recast Qualification Directive) does not apply". (https://ec.europa.eu/home-affairs/what-we-do/networks/ european_migration_network/glossary_search/refugee_en retrieved on 27 October 2019). An immigrant is "a person undertaking an immigration", i.e., "the action by which a person establishes his or her usual residence in the territory of a Member State for a period that is, or is expected to be, of at least 12 months, having previously been usually resident in another Member State or a third country". (https://eur-lex.europa.eu/legal-content/EN/TXT/PDF/? uri=CELEX:32007R0862\&qid $=1585214110432 \&$ from $=E N$, art. 2(b) and (f))
} 
on behalf of the refugees under the "sovereignty clause" (Article 17(1) of the Dublin Regulation) and processed applications in defiance of the Dublin III Regulation 604/2013 which when approved obligated Hungary to accept these refugees under the Schengen accord. ${ }^{6}$ The EU also tried to impose mandatory refugee quotas on the member countries on grounds of solidarity. Hungary, Poland and Slovakia refused to comply creating a crisis of dual sovereignty under the OSTL paradigm that could have been better managed in an MSTL EU.

The idea behind the monetary union is that by pursuing the collective wellbeing of the community (Bergsonian social welfare criterion) leads to superior collective and individual outcomes. Until recently, this idea was shared by all the EU member countries, with the exception of the UK and Denmark. The financial crisis changed this perception, and today $8 \mathrm{EU}$ member states continue to retain their monetary sovereignty. Some comply with the convergence parameters better than many Eurozone countries, but prefer to keep monetary sovereignty because this allows them to coordinate discretionary monetary policies with fiscal policies. If monetary supranationalism is discretionary, then the majority believes that the EU will sacrifice substantial synergies and lose its raison d'être.

\section{THE PERIOD FROM THE FINANCIAL CRISIS TO THE PANDEMIC}

Since the 2008 international financial crisis, the EU political authorities, not the ECB have ultimate power to set and revise transnational aspects of the monetary union. A new institution, the Eurosystem was called into life comprising the ECB and the eurozone countries' central banks. National central banks can only influence monetary policy through this channel, but adjustments are possible. The Eurosystem already accommodates the special needs of the debtor member countries like Greece through special instruments without formally establishing different categories of monetary union membership. The result has been unsatisfactory from more than one perspective. Recently the EU has slowly taken steps that promise to increase the resilience of the monetary union to future shocks. They include the construction of a banking union and reform of the European Stability Mechanism (ESM). ${ }^{7}$ Since the EU is not a perfect optimal currency area (OCA) and lacks a fiscal union, these steps are controversial.

The EU, as it is currently a mixed macroeconomic coordination regime, where some club members operate according to a unified set of monetary rules, while fiscal policy operates independently and is only constrained by the convergence parameters. The mixed system is loosely coordinated, mainly through the EC surveillance, guidance and the peer pressure, as in the European Semester. ${ }^{8}$ However, the system lacks protocols on how dispersed fiscal authorities

\footnotetext{
${ }^{6}$ The fourth reform of the Dublin Convention is presently under discussion.

${ }^{7}$ The ESM replaced the European Financial Stability Facility (EFSF), established in 2010, as an inter-state financial institution to help the Eurozone countries in severe financial distress. It provides emergency loans to Greece, Ireland, Portugal, Spain and Cyprus in return for national reforms. The ESM is the only official institution of the euro area and can lend a total of $€ 700$ billion, financed through financial markets at favorable rates duly passed on to the program countries.

${ }^{8}$ The European Semester provides a framework for the coordination of economic policies across the EU. The European Council created the Semester in 2010 to improve the EU revival after the international crisis and as a part of a wider reform of the EU economic governance. The legal basis for the process is the so-called 'six-pack' - 6 legislative acts that reformed the Stability and Growth Pact. The first European Semester cycle took place in 2011.
} 
(and therefore membership classes) should reconcile conflicts, and in any case, adjustment is left to the countries in distress, with some flexibility in the pace of convergence to the European standards.

The simple truth is that the designers of the EMU disregarded the critical issue of how to deal with the asymmetric consequences of the common monetary policy and exchange rate setting. These asymmetries stem from institutional and structural differences, and specialization shaping production and export responses to exchange and interest rates. Public budget disequilibria generate divergent interest rates which, exacerbated by the austerity policies, jeopardize fiscal stability through fiscal multipliers (Blanchard - Leigh 2013). Nevertheless, the Euro succeeded remarkably for years providing the participating countries with important advantages that fostered growth, employment and public finances stability even in the countries with laggard reforms and investment. ${ }^{9}$

The situation changed with the international financial crisis. Depressed output, unemployment, growing public and private debt, and recurring risks of country default started outweighing the gains from the monetary union. The overall performance of the Eurozone seriously deteriorated and the gap between economically resilient and laggard EMU club members dramatically widened (Dallago 2016).

The main sources of distress in Greece, Italy and in part Cyprus and Portugal were unbalanced public finances and public debts, while in Ireland, Portugal and Spain they were distressed private banks that had to be rescued with public sources. The massive outflow of foreign and domestic capital and the burst of domestic bubbles were fundamental causes of the grave problems in Cyprus, Ireland and Spain (De Grauwe 2011; IMF 2012). Unbalanced and uncompetitive real economies with significant current account deficits also were to blame with the partial exceptions of Ireland and Italy. Various Eurozone countries, including Germany and other Northern countries proved to be more resilient. They had lower public debts (but not overall debts) and more balanced public finances with lower public deficits. Thanks to their strong financial situation, some successful domestic reforms, and favourable Eurozone policies, they were able to accumulate significant current account surpluses. Their current account surpluses and sluggish growth placed other Eurozone countries at a disadvantage. The adjustment burden fell on the distressed individual countries. This impeded macroeconomic adjustment and, in the end, fiscal adjustment, aggravating structural financial and real divergences among the members in the process. Some member countries are to blame for their economic woes, but the EU's institutional flaws exacerbated the matters, together with an increasingly unfavourable external context caused by the most recent developments: the danger of the secular stagnation, the slowdown of international trade, the antagonistic position of the Trump administration, the slowdown of the Chinese economy and the COVID-19 pandemics.

Until the coronavirus pandemic in 2020, the dominant policy approach in the Eurozone required the countries in distress to stabilize their public finances with the austerity policies and regain competitiveness through internal devaluation (Alesina et al. 2019). This had an ameliorative effect in the countries having very open economies and a sizeable inflow of foreign direct investments, such as Ireland and the Baltic states. At the same time, in the countries such

\footnotetext{
${ }^{9}$ The most relevant advantages are lower transaction costs and lack of exchange rate uncertainty in the fundamental infra-European trade, larger and more liquid financial markets, lower interest rates, competitive goods market, transparent prices for their governments, firms, financial organizations, and consumers.
} 
as Greece, Cyprus, Portugal and Italy - with less open economies, suffered acutely. Policies had overall unfavourable effects on economic performance. They depressed the domestic market more than they stimulated exports.

In the recent pre-pandemic period, the EU and the Eurozone adjusted its priorities to deal more forcefully with the negative effects of the austerity policies and internal devaluation (EC 2016). The ECB implemented an expansionary monetary policy and employed non-conventional instruments to support the euro and ease monetary distress (PisaniFerry - Wolff 2012). The European organs started considering exceptional circumstances in softening the convergence parameters and making them more flexible after 2014, defining the budget deficit in structural terms, and adopting a moderately expansionary fiscal stance (EC 2016; ECB 2016). However useful these measures may have been, they did not solve the deep causes of instability, nor complete the EU institutional reform (Draghi 2015, 2019).

The measures created additional problems. Institutional incompleteness, uncoordinated national business cycles and the lack of countercyclical policies led to the accumulation of large stocks of undiversified national public debt securities by national banks. The ensuing banksovereign interdependence created the danger that the adverse shocks to sovereign solvency might intensify the adverse shocks to bank solvency. The ECB initiated its quantitative easing program in March 2015 to the end of 2018, through which it transferred public debt bonds from private banks to national central banks. This eased but did not solve the problem and the ECB had to continue its accommodative monetary policy and de facto debt consolidation into 2019, also by resuming quantitative easing $(\mathrm{QE})$. Some significant yet controversial proposals have emerged, including the construction of a European banking union for large, systemic banks, but real progress has been slight. The EU and the Eurozone need fundamental changes to deliver their promises.

\section{PROPOSALS FOR IMPROVING THE WORKING OF THE EU}

It is impossible to render a definitive judgment on the severity of these problems because social and political attitudes towards immigration are fluid and monetary theory entered uncharted waters after the 2008 financial crisis. The EU's refugee-immigration policy and the transnational macroeconomic regulatory mechanisms are incomplete. There is only a supranational technical instrument to deal with the refugee and related immigration issues and there is no supranational fiscal union. Theorists therefore are free to conjecture that the EU would have weathered the last decade better if a joint refugee-immigration policy existed and transnational macro-regulatory authorities had the tools required to optimize policy. However, this is unprovable. In reality, Europe is a common immigration space without a common strategy. It is not an OCA, nor an optimal fiscal area (OFA). It does not take much imagination to grasp that the fiscal interests of Greece and Germany would have clashed in a fiscal union just as they did in the monetary arena. The only deduction that can be made with confidence is that a common refugee-immigration policy and fiscal union did not contribute to the EU's economic malaise because they did not exist.

Many proposals for deftly managing EU refugee and macroeconomic crises have been vetted. The standard EU approaches stress slowing down and better regulating the inflow of refugees 
and immigrants ${ }^{10}$ and structural reforms to avoid moral hazard. ${ }^{11}$ A haphazard multi-speed union is frequently suggested on both scores, including support for ad hoc instrument such as the "sovereignty clause" and ECB's quantitative easing. The ECB cautions that the accommodative monetary policy can only gain time, without however charting a clear path forward or addressing problems of sequencing. The EC and the national governments advanced various road maps, declarations and proposals. Some important partial reforms such as a move towards a European banking union have been implemented. Yet a real break-through is still lacking.

Recent literatures offer three plausible approaches for improving EU survivability and performance. The first derives from the varieties of capitalism (VoC) literature (Amable 2003, 2016; Dilli et al. 2018; Hall - Soskice 2001; Morgan - Whitley 2012; Soskice 2008). VoC asserts that national microeconomic idiosyncrasies make a common EU currency unworkable. Countries have economic institutions, organizations and systems with unique characteristics (Hall -Thelen 2009). These systems work in different, mutable ways (Schneider - Paunescu 2012). The VoC approach attributes the Eurozone crisis to the inherent contradictions of different economic systems and the euro (Nölke 2016; Johnston - Regan 2016), leading VoC theorists to recommend abandoning the euro and limiting the European integration to the common market.

The second approach advocates softer, expansionary EU policies. It has many advantages but ignores two serious difficulties: moral hazard and equity. While the expansionary policies are likely to mitigate the plight of financially distressed and stagnant economies, giving them time to implement reforms, restructure their industry in an age of low interest rates (Blanchard 2019), it is difficult to guarantee that the stimulus will not be misused or exacerbate the existing inequities. Proponents of the expansionary EU policies deal with the uncertainty by urging the adoption of national reforms to reinvigorate economic growth.

The New Comparative Economics (NCE) paradigm offers a third perspective (Brada 2009; Dallago 2004, 2019; Dallago - Casagrande 2020). It looks at the comparative efficiency properties of institutional and economic change and draws normative consequences for reform (Djankov et al. 2003; Glaeser - Shleifer 2003; Shleifer 2002). Converging to a single system or set of institutions they claim would bolster institutional and economic inefficiency when a mechanism for the resolution of member conflicts is missing. Although not dealing specifically with the EU, NCE predicts that in a system populated with opportunistic agents (countries in the

\footnotetext{
${ }^{10}$ Various means are used, including law enforcement means, a mandatory scheme to relocate immigrants among the member countries and an agreement with Turkey (ECA 2019). Frontex (European Border and Coast Guard Agency) is an EU agency established in 2004 to control Schengen Area borders, in coordination with the national border and coast guards. Its mandate was extended at the end of 2015 to keep illegal immigrants out of the EU or repatriate them. The scheme substantially failed to relocate immigrants to Italy and Greece and caused serious rifts among the countries and within the EC. The agreement with Turkey to host refugees and migrants from Syria in exchange for EU money, visa liberalization and boost to Turkey's access negotiations to the EU also proved to be problematic. A complement to the agreement was the EU financial and technical support to Greece, the frontier country with Turkey to manage the reduced inflow of immigrants. The general problem with this solution is that the deal is possibly at discord with the European and international law and that immigration continues to be managed as an emergency, without a proper common immigration policy.

${ }^{11}$ The mastermind behind this approach is a peculiar mix of a soften neo-liberal approach with the traditional Ordoliberal view (Dullien - Guerot 2012; Sinn 2014; Young 2014). The ongoing intra-Eurozone clash on the nature of ESM and the financial and monetary instruments to be used to fight the economic crisis coming from the health pandemic is a paradigmatic case.
} 
$\mathrm{EU}$ ), a regulatory regime (the EU) is more efficient and effective. The NCE solution may go so far as to imply dissolving the EU and completing its regulatory regime by forming a political union.

All proposals have merits. Perhaps, as VoC theorists suggest, the EU should abandon the monetary union. Perhaps, adopting expansionary policies will save the day. Perhaps, inclusionary economics will cure the EU's malaise. However, the success of any of these recommendations is doubtful because fixing one problem will not fix many other defects. The same reductionist fallacy mars the arguments of "more Europe" and "less Europe" advocates. There is no magic bullet capable of making the EU simultaneously individualistically Pareto efficient, politically potent and socially just (Rosefielde - Pfouts 2014). Economic and political power are endemic, and social justice is in the eyes of the beholder, leaving ample room for the intra-EU conflict. It might seem that a political union offers the only way out of this morass, but this seems more like a dream than a realistic possibility because the EU has never been able to agree on the terms for a constitution. Creating an orderly MSTL system is a more promising option.

\section{THE MSTL PERSPECTIVE}

The EU's founders from the start were evasive about whether supranationalism was practical or ideal. If the EU were merely a framework for cooperation, it could take diverse forms. If it were more, then it was the politicians' duty to choose the best arrangement. The EU leaders punted on the issue, assuming that the Treaty of Rome was practical enough and that whatever form the union took ultimately, it would be unique and the best. The ensuing tug of war between advocates of "more Europe" and "less Europe" provided a forum for debating the EU's endgame. The arguments for and against "more Europe" twisted and turned variously stressing efficiency, equity, ideals and political power.

The pretence worked well enough until the centripetal forces unleashed by the 2008 financial crisis started unhinging the entire project. The tug of war between advocates of "more Europe" and "less Europe" became an obstacle to progress because it diverted attention from the practical task of preventing the EU's internal degeneration. In the end, the debate is moving in the direction of the fundamental distinction between the Eurozone countries, where more Europe is necessary and inevitable, and those countries among the others which want to remain outside and may be happier with less Europe. The new imperative is to re-conceptualize the EU as an adaptive socially and politically inclusive, Pareto improving satisfying project with a flexible internal structure. The members must decide how much national sovereignty they wish to preserve. The formal MSTL joint authority (shared sovereignty) should be institutionalized to facilitate the resolution of contentious issues.

The EU has already taken some important steps to increase flexibility. The Euro Plus Pact $(\mathrm{E}+\mathrm{P})$, adopted in March 2011 redefined the primary deficit to lessen the compliance burden. The new rule excluded the zero-output gap (the gap between current GDP and potential GDP) from the deficit calculation, a measure that implicitly favoured the most indebted countries. The suspension of the Stability and Growth Pact during the 2020 pandemic gave the members additional degrees of freedom on an emergency basis.

The 2010 European Semester serves a similar eclectic purpose. It is a series of regularly scheduled fora created to foster national fiscal policy coordination, structural reforms and 
macroeconomic imbalances discussions, based on commonly agreed rules and standards. The consultation process is not a joint sovereignty and has a limited short-term perspective but it is a step in the right direction. The Semester supported the implementation of the Europe 2020 growth strategy. Following the international crisis, the EU decided in the "more Europe" spirit to implement a stronger economic governance and better policy coordination, synchronization and monitoring among the member states to improve convergence, stability and other EU objectives, pushing the growth agenda into the background.

The EU took another small step in the same spirit in November 2018. The EC prepared an analysis of the Eurozone economy clarifying the EU's economic and financial philosophy and related instruments and areas of intervention for promoting the convergence and coordination of the Eurozone member countries (EC 2018). The document included an EU Reform Support Programme, a European Investment Stabilization Function and a European Monetary Fund. These instruments, if implemented, may become important for allowing institutionally and structurally different member countries to integrate without having to transform their systems, to pursue the same goals and share the same currency, along different tracks.

A subsequent Council of the EU document on the Eurozone (CEU 2019) addressed the same issues. It states that: "The strengthening of fiscal sustainability of the euro area and its Member States requires differentiated national policies in full respect of the Stability and Growth Pact, taking into account fiscal space and spillovers across countries."

A Commission document on the 2019 European Semester (EC 2019) stressed that "While not all investment needs can be addressed by EU funds, these provide considerable opportunities to addressing the concrete investment gaps identified in the country-specific recommendations." And, further on: "The strengthening of fiscal sustainability of the euro area and its Member States requires differentiated national fiscal policies." Both reports and recommendations for each member state presented highly differentiated reform landscapes that clearly go in the direction of a well-ordered MSTL Union.

The basic principle guiding the construction of a well-order MSTL union is that everything not explicitly prohibited in the EU treaties should be allowed, if policies do not create negative macroeconomic spillovers. Everything else should be negotiated without preconditions. If there are spillovers, compensation should be given according to the pre-established and verifiable rules and parameters, guided with a long-term perspective. Political debate will be inevitable, but the well-ordered MSTL approach lubricates the integration process, making it more flexible and effective.

For example, Article 122 of the consolidated version of the Treaty on the Functioning of the EU stipulates that "1. Without prejudice to any other procedures provided for in the Treaties, the Council, on a proposal from the Commission, may decide, in a spirit of solidarity between the Member States, upon the measures appropriate to the economic situation, in particular if severe difficulties arise in the supply of certain products, notably in the area of energy. 2 . Where a Member State is in difficulties or is seriously threatened with severe difficulties caused by natural disasters or exceptional occurrences beyond its control, the Council, on a proposal from the Commission, may grant, under certain conditions, Union financial assistance to the Member State concerned. The President of the Council shall inform the European Parliament of the decision taken."

Clearly there is an ample room for interpretation and political bargaining here. The principles of flexibility, adaptation and solidarity are clearly stated, but important ambiguities 
remain. What measures are "appropriate to the economic situation"? What are the "certain conditions"? Does this mean that the EU may lend money or countries take higher number of immigrants or assist a number of victims of the coronavirus pandemic from the countries in greater difficulty? Or does this mean that the EU should issue bonds on behalf of the country in need?

The well-ordered MSTL approach is more transparent. It implies that the EU offices established in the country of first entry and financed by common resources should determine refugee and immigration applications. Economic immigrants should be allowed to enter the country of settlement if the country agrees. Refugees should be distributed in proportional quotas to all member countries and in accordance with the international and EU requirements. This could generate negative consequences and costs for particular countries, but they could be managed with appropriate co-sharing rules that mitigate losses. Competently designed rules and policies permit the benefits of stabilization and EU reinvigoration to outweigh the costs, especially if the EU sets sensible national quotas on refugee distribution. If a country cannot or does not want to accept refugees, the country should pay compensation to the countries willing to take its quotas or engage to accept a higher quota at a later time.

The monetary and financial case is more demanding. Let us take the case of a financially distressed country willing to remedy the deep causes of its distress through institutional and structural reforms. This may require giving a priority to costly reforms and policies to support growth, postponing budgetary rebalancing. There are three critical issues in this case: the credibility of reforms and growth policies, their costs, the assessment of their outcomes and effect on public finances. A credible third party is needed, which can only be the EC or a delegated common organ, under the supervision of the European Parliament. The interested country should present a detailed plan of measures and timing, and appeal for a special track (a Convergence Track). If the delegated organ approves the plan, the country should be exempted from the convergence parameters for a pre-established period of time. The EU organs (including the ECB) also might be permitted to provide resources for implementing reforms on favourable terms, because the entire Union benefits. The only hard rule should be that debts incurred should be honoured by the country. The third party should obviously have the way to assess implementation and, if needed, enforce the deal. Here the method of the European Semester can be useful and give transparency to the process. If these conditions hold, chances are that markets should trust the country on the special track.

The advantages of the orderly MSTL approach over the OSTL concept are manifold. First, each country would be on a clear track, which would give transparency to the process and facilitate compliance. Second, national preferences would be clarified speeding conflict resolution. Third, the ailing members would have more time to correct structural problems. Fourth, solidarity would be enhanced. In short, orderly MSTL will prove that the EU and Eurozone have both sticks and carrots for promoting compliance and cooperation.

\section{CONCLUSIONS}

The essence of the MSTL proposal is that, lacking a political union, the member countries' institutional and structural idiosyncrasies become the part of a new deal in a sustainable win- 
win perspective. This is particularly important and urgent in the Eurozone, where policy and institutionally based negative spillovers threaten financial stability, depress growth and make inter-country divergences permanent. The way for solving such dangers is to prolong the time horizon of both the EU and the member countries and set up credible assessments, guarantees and enforcement against moral hazard through the MSTL cooperative perspective.

Although in the long run the MSTL perspective would gain from a revision of the treaties, its experimentation and practical use easily fits the present treaties if longer-term and learning by doing perspectives prevail. Moving in this direction, as the EU is slowly doing, also serves to build trust among the member countries, an essential ingredient for the success of the perspective.

The paper offers two examples: the monetary union and immigration. In the Economic and Monetary Union, the common monetary policy is used to counteract the symmetrical shocks and fiscal policies remain with the member countries to deal with the asymmetric shocks. Although politically appealing, fiscal discipline through the convergence parameters soon appeared fundamental to counteract the danger of moral hazard. Although originally foreseen in a longer-time perspective, the yearly compliance became paramount since the crisis and pushed growth in the background. In an attempt to attenuate and counteract the devastating consequences of the crisis for both stability and, even more so, growth, the EU started to consider exceptional circumstances, along with a supportive monetary policy. This attempt was sufficient to keep all countries afloat but failed in promoting fiscal balances in line with the convergence parameters in the distressed countries and fostering growth even in the better-balanced countries. Similarly, a common feasible immigration policy is still missing in the EU. Refugees and immigrants' issues are considered under the pressure of mass inflow of people and are thus under the pressure coming from the need to find short-term solutions to a secular and structural problem. The MSTL perspective cannot solve the problems for good, but helps in providing an orderly and flexible management.

All these issues are on the EU desk, yet stalemate is looming around. The MSTL perspective would rationalize and institutionalize the EU's response mechanism in flexible ways that facilitate adaptation by prolonging the time horizon, giving transparency to different tracks and developing instruments for both support to and compliance of the member countries. It would put collective solidarity and individual responsibility in a cooperative perspective, through EU leadership and political compromise among the member countries to make a novel use of the already existing provisions of the treaties, such as the mentioned Art. 122 TFEU. Experiences gained would then lead the EU to see whether a change of the treaties is necessary or not and in which way, in a learning by doing perspective.

Reimaging the EU as an orderly MSTL project provides both an alternative Bergsonian ideal, and a practical, flexible and adaptive strategy for building cooperative coalitions, reinvigorating growth, closing development gaps, improving macroeconomic coordination, ameliorating negative spillovers, dampening antagonisms and strengthening solidarity in pursuit of the EU's founding social ideals. An orderly MSTL system should benefit the Eurozone, non-Eurozone members and the entire club. There is a place for a host of targeted reforms proposals within the MSTL framework, and an orderly MSTL union should be Bergsonian improving without a downside. 


\section{REFERENCES}

Acemoglu, D. - Robinson, J. (2012): Why Nations Fail: The Origins of Power, Prosperity and Poverty. New York: Crown Business.

Alesina, A. - Favero, C. - Giavazzi, F. (2019): Austerity. When it Works and When it Doesn't. Princeton: Princeton University Press.

Amable, B. (2003): The Diversity of Modern Capitalism. Oxford: Oxford University Press.

Amable, B. (2016): Institutional Complementarities in the Dynamic Comparative Analysis of Capitalism. Journal of Institutional Economics, 12(1): 79-103.

Andreozzi, L. - Tamborini, R. (2019): Models of Supranational Policymaking and the Reform of the EMU. Journal of Policy Modeling, 41(5): 819-844.

Bellamy, R. - Kröger, S. (2017): A Democratic Justification of Differentiated Integration in a Heterogeneous

EU. Journal of European Integration, 39(5): 625-639.

Bergson, A. (1938): A Reformulation of Certain Aspects of Welfare Economics. Quarterly Journal of Economics, 52(1): 310-334.

Bergson, A. (1954): The Concept of Social Welfare. Quarterly Journal of Economics, 68(2): 233-253.

Bergson, A. (1976): Social Choice under Representative Government. Journal of Public Economics, 6(3): 171-190.

Blanchard, O. (2019): Public Debt and Low Interest Rates. The American Economic Review, 109(4): 11971229.

Blanchard, O. - Leigh, D. (2013): Growth Forecast Errors and Fiscal Multipliers. IMF Working Paper, No: WP/13/1, January.

Brada, J. C. (2009): The New Comparative Economics versus the Old: Less Is More but Is It Enough? The European Journal of Comparative Economics, 6(1): 3-15.

Brunnermeier, M. - James, H. - Landau, J. P. (2016): The Euro and the Battle of Ideas. Princeton: Princeton University Press.

Council of the European Union (CEU) (2019): Recommendation on the Economic Policy of the Euro Area. Brussels, 11 January 2019 (OR. en) 5097/19 https://www.consilium.europa.eu/media/37893/st_5097_ 2019_init_en.pdf.

Dallago, B. (2004): Comparative Economic Systems and the New Comparative Economics. The European Journal of Comparative Economics, 1(1): 59-86.

Dallago, B. (2016): One Currency, Two Europes. Towards a Dual Eurozone. Singapore: World Scientific.

Dallago, B. (2019): Comparative Economics, Globalisation and the Eurozone in the Quest for a New Eurozone Paradigm. Acta Oeconomica, 69(S1): 99-120.

Dallago, B. - Casagrande, S. (2020): The "New Comparative Economics". A Critical Review. In: Havrylyshyn, O. - Douarin, E. (eds): The Palgrave Handbook of Comparative Economics. London: Palgrave Macmillan, pp. 91-117.

De Grauwe, P. (2011): The Governance of a Fragile Eurozone. CEPS Working Documents, May. Online. Available http://ceps.eu/book/governance-fragile-eurozone.

De Witte, B. (2018): An Undivided Union? Differentiated Integration in Post-Brexit Times. Common Market Law Review, 55(2/3): 227-250.

Dilli, S. - Elert, N. - Herrmann, A. M. (2018): Varieties of Entrepreneurship: Exploring the Institutional Foundations of Different Entrepreneurship Types through 'Varieties-of-Capitalism'. Arguments. Small Business Economics, 51(6): 293-320. 
Djankov, S. - Glaeser, E. - La Porta, R. - Lopez-de-Silanes, F. - Shleifer, A. (2003): The New Comparative Economics. Journal of Comparative Economics, 31(4): 595-619.

Draghi, M. (2015): Introductory Statement at the Italian Parliament. Speech by Mario Draghi, President of the ECB, at the Italian Parliament, Rome, 26 March 2015. http://www.ecb.europa.eu/press/key/date/ 2015/html/sp150326.en.html.

Draghi, M. (2019): Monetary Dialogue with Mario Draghi (pursuant to Article 284(3) TFEU), Brussels, 23 September, European Parliament, Committee on Economic and Monetary Affairs. https://www. europarl.europa.eu/cmsdata/187423/CRE_Monetary_dialogue_230919-original.pdf.

Dullien, S. - Guerot, U. (2012): The Long Shadow of Ordoliberalism: Germany's Approach to the Euro Crisis. European Council on Foreign Relations, Policy Brief, ECFR/49, February.

EC (2016): Towards a Positive Euro Area Fiscal Stance Supporting Public Investments that Increase Economic Growth. EPSC Strategic Notes, No. 20, 23 November, Brussels.

EC (2018): Analysis of the Euro Area Economy. Accompanying the Document Recommendation on the Economic Policy of the Euro Area, Commission Staff Working Document, Brussels, 21.11.2018 SWD (2018) 467 final \{COM (2018) 759 final\}.

EC (2019): 2019 European Semester: Country-Specific Recommendations. Communication to the European Parliament, the European Council, the Council, the European Central Bank, the European Economic and Social Committee, the Committee of the Regions and the European Investment Bank, Brussels, 5.6.2019 $\operatorname{COM}(2019) 500$ final.

ECA (2019): Asylum, Relocation and Return of Migrants: Time to Step Up Action to Address Disparities between Objectives and Results. Special Report, No. 24, Luxembourg: European Court of Auditors.

ECB (2016): The Euro Area Fiscal Stance. ECB Economic Bulletin, 4: 68-87.

Fabbrini, S. (2019): Europe's Future: Decoupling and Reforming. Cambridge: Cambridge University Press.

Glaeser, E. - Shleifer, A. (2003): The Rise of the Regulatory State. Journal of Economic Literature, 41(2): 401-425.

Hall, P. A. - Soskice, D. W. (eds) (2001): Varieties of Capitalism. The Institutional Foundations of Comparative Advantage. Oxford: Oxford University Press.

Hall, P. A. - Thelen, K. (2009): Institutional Change in Varieties of Capitalism. Socio-Economic Review, 7(1): 7-34.

IMF (2012): Global Financial Stability Report. Restoring Confidence and Progressing on Reforms. Washington, DC.

Johnston, A. - Regan, A. (2016): European Monetary Integration and the Incompatibility of National Varieties of Capitalism. Journal of Common Market Studies, 54(2): 318-336.

Ling, J. (2017): Reshaping the Path: Tackling the European Integration Dilemma. China International Studies, 65: 42-59.

Mody, A. (2018): EuroTragedy. A Drama in Nine Acts. Oxford: Oxford University Press.

Morgan, G. - Whitley, R. (eds) (2012): Capitalisms and Capitalism in the Twenty-First Century. Oxford: Oxford University Press.

Nölke, A. (2016): Economic Causes of the Eurozone Crisis: The Analytical Contribution of Comparative Capitalism. Socio-Economic Review, 14(1): 141-161.

Pisani-Ferry, J. (2014): The Euro Crisis and its Aftermath. Oxford: Oxford University Press.

Pisani-Ferry, J. - Wolff, G. (2012): Is LTRO QE in Disguise? VoxEu, May 3. (http://www.voxeu.org/article/ ltro-quantitative-easing-disguise).

Rosefielde, S. - Pfouts, R. (2014): Inclusive Economic Theory. Singapore: World Scientific Publishers. 
Saint-Simon, Claude-Henri de Rouvroy comte de (1814): De la réorganisation de la société Européenne. Paris: Adrien Égron.

Schneider, M. R. - Paunescu, M. (2012): Changing Varieties of Capitalism and Revealed Comparative Advantages from 1990 to 2005: A Test of the Hall and Soskice Claims. Socio-Economic Review, 10(4): 731-753.

Scicluna, N. (2018): Integration through the Disintegration of Law? The ECB and EU Constitutionalism in Crisis. Journal of European Public Policy, 25(12): 1874-1891.

Scipioni, M. (2018): Failing Forward in EU Migration Policy? EU Integration after the 2015 Asylum and Migration Crisis. Journal of European Public Policy, 25(9): 1357-1375.

Shleifer, A. (2002): The New Comparative Economics. NBER Reporter, Fall: 12-15.

Sinn, H. W. (2014): The Euro Trap. On Bursting Bubbles, Budgets, and Beliefs. Oxford: Oxford University Press.

Soskice, D. (2008): Varieties of Capitalism and Macroeconomic Institutions. In: Hancke, B. - Rhodes, M. Thatcher, M. (eds): Beyond Varieties of Capitalism. Oxford: Oxford University Press, pp. 88-120.

Stiglitz, J. E. (2016): The Euro: How a Common Currency Threatens the Future of Europe. New York: W.W. Norton \& Company.

Telò, M. (2017): The Present and Future of the European Union, between the Urgent Need for Democracy and Differentiated Integration. In: Vanhercke, B. - Sabato, S. - Bouget, D. (eds): Social Policy in the European Union: State of Play 2017. Brussels: ETUI, pp: 15-31.

Wahl, P. (2017): Between Eurotopia and Nationalism: A Third Way for the Future of the EU. Globalizations, 14(1): 157-163.

Young, B. (2014): German Ordoliberalism as Agenda Setter for the Euro Crisis: Myth Trumps Reality. Journal of Contemporary European Studies, 22(3): 276-287. 